\title{
ECOLOGICAL FEATURES OF GROUPS OF ROVE BEETLES (Coleoptera: Staphylinidae) IN BEECH FOREST ECOSYSTEMS OF THE LOWER FOREST BELT OF THE GORGAN MASSIF
}

\author{
M. Lutska, A. Sirenko
}

\begin{abstract}
Purpose: to study the species composition of groups of predatory beetles in beech forests of the lower forest belt of the Gorgan massif and their ecological features.

Materials and methods. Representatives of 54 species from 12 subfamilies. Identification of the reveal species was performed using Bay-Bienko (1965), Bohac J (1985 a, b), Coiffait, H., (1974, 1984), Lohse, G. A., (1964, 1974) determinants. Determination of dominance groups by the Stecker-Bergman method (1977), establishment of ecological and morphological groups according to Kashcheev V. A. (1982, 1985, 1999), types of life strategies according to Planck's method, Belonging to zoogeographical groups was established by the Vtorov P. P., Drozdov N. N. (2001).

Research results. According to the results of the research, 556 individuals of rove beetles belonging to 28 genera were found, which are located within 12 subfamilies. The highest level of species diversity is characterized by the subfamilies Staphylininae and Tachyporinae, which are represented by 21 and 13 species, respectively. Only one dominant species was found in the structure of dominance - Tasgius (Rayacheila) bicharicus Mull., 1825, however, a high number of subrecent species is observed. The identified species are representatives of eleven ecological and morphological groups. Analysis of the trophic specialization of predatory beetles has shown a clear dominance of predators, among which there are both specialized species and polyphagous. The analysis of life strategies revealed representatives of 7 groups, and zoogeographical features - 10.

Conclusions. Among the species of predatory beetles caught, there is a clear dominance of tachyporin and staphylin, which total $62.9 \%$ The study of the dominance structure of this group showed a small proportion of mass species, and a clear redominance of recedents and subrecedents. According to the analysis of ecomorphs, there is an increase in the number of wells and cryptobionts, as well as mixotrophs, due to the significant level of ecological niches that are inherent in the analyzed type of ecosystems
\end{abstract}

Keywords: Staphylinidae, groups, ecological and morphological groups, life strategies, beech forests

Copyright (C) 2020, M. Lutska, A. Sirenko. This is an open access article under the CC BY license (http://creativecommons.org/licenses/by/4.0).

\section{Introduction}

Predatory beetles (Staphylinidae, Coleoptera, Insecta) are one of the largest families of Coleoptera on our planet, distributed in all types of terrestrial ecosystems: steppes, fields, meadows, forests near ponds, although there are no aquatic species among them [1].

Staphylinidae play a particularly important role in forests, where they are one of the most numerous groups of arthropods. In this type of ecosystems, they occur in a variety of substrates of existence: forest litter, plant and animal remains, feces of wild or domestic animals, fruiting bodies of fungi, as well as under mosses and algae [2, 3]. In all types of substrates of existence, the representatives of the studied family are active zoophagous, which intensively reduce the number of forest and agricultural pests, as well as nematophages, which regulate the number of animal helminths. Many species of predatory beetles are saprophages that accelerate the decomposition of dead organic matter $[4,5]$.

Given the important regulatory role of Staphylinidae in ecosystems, their resistance to environmental factors $[6,7]$ and significant numbers in biogeocenoses, they are an important zoological and ecological group of living organisms used to monitor the environment. This aspect necessitates the study of the species diversity of predatory beetles and their ecological features at the regional level.

\section{Literature review}

The beginning of research covering information about predatory beetles of the Gorgan massif dates back to the second half of the XIX century [8-10]. First of all, they cover the issues of faunal diversity of Staphylinidae within the analyzed areas, providing only annotated lists of species, regardless of habitat or seasonal activity.

Thorough ecological and faunal research of predatory beetles was conducted by $\mathrm{O}$. Yu. Mateleshko, who covered the information on the height distribution of Staphylinidae in the Ukrainian Carpathians according to the plant zonation. It is established that with increasing altitude there is a decrease in species richness of this family. Thus, the subalpine belt is characterized by representatives of only ten species: Saulcyella schmidti Maerkel, 1844, Bryaxis ruthenus Saulcy, 1877, Pselaphus heisei Herbst, 1792, Esphalerum lapponicum, Eusphalerum primulare, (Paykull, 1789), Amphichroum canaliculatum (Erichson, 1840), Anotylus tetracarinathus (Block, 1799), Othius crassus Motschulsky, 1858, Que- 
dius paradisianus (Heer, 1839), and in the Alpine they are not found [11].

Clear relationships between predatory beetles and fungi, in particular sulfur-yellow codling moths, have been established, and the peculiarities of changes in their species diversity at different stages of decay have been analyzed [12]. Peculiarities of formation of relationships of predatory beetles with different species of insects, as well as peculiarities of formation of their groups in hollows of coniferous and deciduous trees with the analysis of seasonal activity were analyzed [2].

\section{The purpose and objectives of the study}

The aim of this work was to investigate the species composition of stratobiont predatory beetle groups in the beeches of the lower forest belt of the Gorgan massif, and to analyze their ecological features.

To achieve this goal, the following tasks were set:

1. To study the species diversity of stratobiont predatory beetles in the beech forests of the lower Gorgan forest belt;

2. Establish the structure of dominance in the stratobiont Staphylinidae groups in beeches;

3 . To analyze the ecological features in the groups of stratobiont predatory beetles within the beech forests of the lower Gorgan forest belt.

\section{Materials and methods of research}

The analysis of the material was carried out during the warm period of 2016-2017 in beeches growing at an altitude of 300-800 meters above sea level. The analyzed place is located on the terraces at the confluence of the rivers Zubrivka and Fedocil. Geographic coordinates: $48^{\circ} 49^{\prime} \mathrm{N} ; 24^{\circ} 46^{\prime} \mathrm{E}$ d. The nearest settlement $-\mathrm{Ze}$ lene, Nadvirna district, Ivano-Frankivsk region. The height above sea level is $780 \mathrm{~m}$, the studied area is 0.03 ha. As a result of the conducted researches 533 individuals of beetles of predators belonging to 54 species were revealed.

To analyze the structure of groups of Gorgan beetles, Berber soil traps, forest litter sifting, manual collection and survey of vegetation were used. Beetles were collected in accordance with generally accepted soil and zoological methods [13, 14].

The identified species were determined using determinants [15-19], the structure of dominance was determined by the Stecker-Bergman system [20]. Assessment of ecological and morphological groups was performed according to the method of Kashcheev [21, 22]. The life strategies of the identified species were determined by Planck's criteria. Zoological and geographical groups classified according to P. P. Vtorov, N. N. Drozdov [23].

\section{Research results}

As a result of the conducted researches it was established that the grouping of stratobiont Staphylinidae in ecosystems of beech forests of the lower forest belt of the Gorgan massif consists of 54 species belonging to 28 genera and 12 subfamilies.

Within the studied ecosystem, the highest level of species diversity is characterized by Staphylininae and Tachyporinae, which are represented by 21 and 13 species, respectively. The vast majority of subfamilies found within the analyzed biogeocenosis are represented by one or two species (Table 1).

Table 1

Total number of individuals and \% of identified staphylinide species in the beech forest ecosystem of the lower forest belt of the Gorgan massif

\begin{tabular}{|c|c|c|c|c|c|c|c|}
\hline № & Species & $\begin{array}{l}\text { Number of } \\
\text { individuals }\end{array}$ & $\%$ & $\begin{array}{l}\text { Domi- } \\
\text { nance } \\
\text { groups }\end{array}$ & Ecomorph & $\begin{array}{l}\text { Trophic } \\
\text { speciali- } \\
\text { zation }\end{array}$ & $\begin{array}{l}\text { Life } \\
\text { strategy }\end{array}$ \\
\hline 1 & 2 & 3 & 4 & 5 & 6 & 7 & 8 \\
\hline \multicolumn{8}{|c|}{ OMALIINAE } \\
\hline 1 & Siagonium humerale Ger.,1836 & 4 & 0,7 & SR & ERSC & $\mathrm{Z}$ & $\mathrm{S}$ \\
\hline 2 & $\begin{array}{lll}\text { Siagonium } & \text { quadricorne } & \text { Kir- } \\
\text { by\&Sp.,1815 }\end{array}$ & 6 & 1,2 & $\mathrm{R}$ & WRSCH & $\mathrm{Z}$ & $\mathrm{R}$ \\
\hline 3 & Acrulia inflata(Gyll.,1813) & 8 & 1,5 & $\mathrm{R}$ & ERS & $\mathrm{Z}$ & $\mathrm{R}$ \\
\hline 4 & Omalium caesum Grav.,1806 & 1 & 0,2 & SR & ERS & Z-M & $\mathrm{S}$ \\
\hline 5 & Omalium rivulare Payk.,1789 & 10 & 1,9 & $\mathrm{R}$ & ERS & $\mathrm{Z}$ & $\mathrm{S}$ \\
\hline 6 & Phloeonomus minimus Erich.,1839 & 5 & 1 & SR & ERS & $\mathrm{Z}$ & $\mathrm{R}$ \\
\hline 7 & Phloeostiba planaPayk.,1792 & 1 & 0,2 & SR & ERS & $\mathrm{Z}$ & $\mathrm{R}$ \\
\hline \multicolumn{8}{|c|}{ MICROPEPLINAE } \\
\hline 8 & Micropeplus fulvipes Kerst.,1964 & 1 & 0,2 & SR & ERS & $\mathrm{M}$ & $\mathrm{S}$ \\
\hline \multicolumn{8}{|c|}{ EUSPHALERINAE } \\
\hline 9 & Eusphalerum primulare & 19 & 3,7 & SD & ERS & $\mathrm{Z}$ & SR \\
\hline \multicolumn{8}{|c|}{ OXYTELINAE } \\
\hline 10 & $\begin{array}{lll}\text { Oxytelus } & \text { (Epomotylus) } & \text { sculptus } \\
\text { Grav.,1806 } & & \\
\end{array}$ & 16 & 3.0 & $\mathrm{R}$ & $\mathrm{CRC}$ & $\mathrm{N}$ & $\mathrm{R}$ \\
\hline 11 & Syntomium aeneum (Mull.,1821) & 16 & 3.0 & $\mathrm{R}$ & ERS & Z-S & $\mathrm{R}$ \\
\hline 12 & $\begin{array}{l}\text { Scaphidium } \quad \text { quadrimaculatumKir- } \\
\text { by\&Sp.,1815 }\end{array}$ & 5 & 1 & SR & ERS & $\mathrm{Z}$ & $\mathrm{R}$ \\
\hline \multicolumn{8}{|c|}{ TRIGONURINAE } \\
\hline 13 & Scaphisoma assimileErich.,1845 & 8 & 1,5 & $\mathrm{R}$ & ERS & $\mathrm{Z}$ & $\mathrm{R}$ \\
\hline
\end{tabular}


continuation of Table 1

\begin{tabular}{|c|c|c|c|c|c|c|c|}
\hline 1 & 2 & 3 & 4 & 5 & 6 & 7 & 8 \\
\hline \multicolumn{8}{|c|}{ STAPHYLININAE } \\
\hline 14 & Gabrius splendidulus (Grav.,1802) & 10 & 1,9 & $\mathrm{R}$ & ERS & $\mathrm{Z}$ & $\mathrm{R}$ \\
\hline 15 & Atrecus longicepsFauv.,1873 & 15 & 2,9 & $\mathrm{R}$ & CDS & $\mathrm{Z}$ & $\mathrm{R}$ \\
\hline 16 & Abemus chloropterus Panz.,1796 & 25 & 4.8 & SD & ERS & $\mathrm{Z}$ & $\mathrm{C}$ \\
\hline 17 & Nudobius lenthus Grav.,1806 & 33 & 6.3 & SD & CDS & $\mathrm{Z}$ & $\mathrm{R}$ \\
\hline 18 & $\begin{array}{l}\text { Tasgius } \\
\text { Mull.,1825 }\end{array}$ & 68 & 13 & $\mathrm{D}$ & WDS & $\mathrm{Z}$ & $\mathrm{C}$ \\
\hline 19 & $\begin{array}{l}\text { Tasgius (Rayacheila) morsitans com- } \\
\text { pressus Marsh.,1806 }\end{array}$ & 24 & 4,6 & SD & WDS & $\mathrm{Z}$ & $\mathrm{CR}$ \\
\hline 20 & Othius pucntulatus & 5 & 1 & SR & WRS & $\mathrm{Z}$ & $\mathrm{CS}$ \\
\hline 21 & $\begin{array}{l}\begin{array}{l}\text { Philonthus } \\
\text { (Gyll.,1810) }\end{array} \\
\text { ventralis immundus }\end{array}$ & 14 & 2,7 & $\mathrm{R}$ & WRC & $\mathrm{N}$ & $\mathrm{R}$ \\
\hline 22 & Philonthus decorus (Grav.,1802) & 6 & 1,2 & $\mathrm{R}$ & WRC & $\mathrm{N}$ & $\mathrm{CR}$ \\
\hline 23 & $\begin{array}{l}\text { Philonthus (Onychophilonthus) mar- } \\
\text { ginatus }\end{array}$ & 4 & 0,7 & SR & ERS & $\mathrm{Z}$ & $\mathrm{R}$ \\
\hline 24 & Philonthus rubripennis Steph.,1832 & 5 & 1 & SR & CPK & $\mathrm{Z}$ & $\mathrm{R}$ \\
\hline 25 & Philonthus longicornis Steph.,1832 & 23 & 4,4 & SD & WRC & $\mathrm{Z}$ & $\mathrm{R}$ \\
\hline 26 & Philonthus nitidus (Fab.,1787) & 2 & 0,4 & SR & WRC & $\mathrm{Z}$ & $\mathrm{R}$ \\
\hline 27 & Quedius paradisianus (Heer.,1839) & 10 & 1,9 & $\mathrm{R}$ & $\mathrm{CPK}$ & $\mathrm{Z}$ & $\mathrm{CR}$ \\
\hline 28 & Quedius xanthopus Erich.,1839 & 3 & 0,3 & SR & WRC & $\mathrm{Z}$ & $\mathrm{CR}$ \\
\hline 29 & $\begin{array}{lll}\text { Staphylinus } & \text { caesereus } & \text { caesere- } \\
\text { usCeder.,1798 }\end{array}$ & 35 & 6,7 & SD & ERS & $\mathrm{Z}$ & SR \\
\hline 30 & $\begin{array}{l}\text { Staphylinus erythropterus erythropter- } \\
\text { us L., } 1758\end{array}$ & 35 & 6,7 & SD & ERS & $\mathrm{Z}$ & SR \\
\hline 31 & Hypnogyra angularis & 2 & 0,4 & SR & CRS & $\mathrm{Z}$ & $\mathrm{R}$ \\
\hline 32 & $\begin{array}{l}\text { Xantholinus } \\
\text { (Oliv.,1794) }\end{array} \quad$ linearis $\quad$ linearis & 2 & 0,4 & SR & CRS & Z-S & $\mathrm{R}$ \\
\hline 33 & $\begin{array}{lll}\begin{array}{l}\text { Xantholinus } \\
\text { (Fab.,1787) }\end{array} & \text { (Purrolinus) } & \text { tricolor } \\
\end{array}$ & 1 & 0,2 & SR & CRS & Z-S & $\mathrm{R}$ \\
\hline \multicolumn{8}{|c|}{ OXYPORINAE } \\
\hline 34 & Oxyporus maxillosus Fab.,1793 & 18 & 3,5 & SD & WDM & $\mathrm{M}$ & $\mathrm{R}$ \\
\hline 35 & Oxyporus rufus rufus L., 1758 & 9 & 1,7 & $\mathrm{R}$ & WDM & Z-M & SR \\
\hline \multicolumn{8}{|c|}{ STENINAE } \\
\hline 36 & Stenus carpathicus Ganglb.,1896 & 17 & 3,3 & SD & ERSC & $\mathrm{Z}$ & SR \\
\hline 37 & Stenus comma comma LeC.,1863 & 11 & 2.1 & $\mathrm{R}$ & ERSC & $\mathrm{Z}$ & $\mathrm{R}$ \\
\hline 38 & Stenus humilisErich.,1839 & 5 & 1 & SR & ERSC & $\mathrm{Z}$ & SR \\
\hline 39 & Stenus geniculatus Grav.,1802 & 2 & 0,4 & SR & ERSC & $\mathrm{Z}$ & SR \\
\hline \multicolumn{8}{|c|}{ TACHYPORINAE } \\
\hline 40 & Trichophya pilicornis (Gyll.,1810) & 2 & 0,4 & SR & ERSC & $\mathrm{Z}$ & SR \\
\hline 41 & Lordithon exoletus (Erich.,1839) & 3 & 0,6 & SR & CDS & $\mathrm{Z}$ & $\mathrm{S}$ \\
\hline 42 & Lordithon lunulatus (L.,1760) & 11 & 2.1 & $\mathrm{R}$ & CDS & Z-M & $\mathrm{CS}$ \\
\hline 43 & Lordithon trinotatus (Erich.,1839) & 5 & 1 & SR & CDS & $\mathrm{Z}$ & CS \\
\hline 44 & Lordithon speciosus Erich.,1839 & 1 & 0,2 & SR & CDS & $\mathrm{Z}$ & SR \\
\hline 45 & Lordithon trimaculatus (Fab.,1793) & 1 & 0,2 & SR & CDS & Z-S & SR \\
\hline 46 & Sepedophilus bipustulatus Grav.,1802 & 2 & 0,4 & SR & WRM & $\mathrm{Z}$ & $\mathrm{R}$ \\
\hline 47 & Sepedophilus testaceus (Fab.,1793) & 1 & 0,2 & SR & WRM & $\mathrm{Z}$ & $\mathrm{R}$ \\
\hline 48 & Tachinus rufipes (L.,1758) & 3 & 0,6 & SR & ERSC & Z-M & SR \\
\hline 49 & Tachinus humeralis Grav.,1802 & 2 & 0,4 & SR & ERSC & $\mathrm{Z}$ & $\mathrm{S}$ \\
\hline 50 & Tachinus subterraneus (L.1758) & 2 & 0,4 & SR & ERSC & $\mathrm{Z}$ & $\mathrm{S}$ \\
\hline 51 & Tachyporus formossus (Matt.,1838) & 10 & 1,9 & $\mathrm{R}$ & ERSC & $\mathrm{Z}$ & $\mathrm{R}$ \\
\hline 52 & Tachyporus hypnorum (Fab.,1775) & 1 & 0,2 & SR & ERSC & $\mathrm{Z}$ & $\mathrm{R}$ \\
\hline 53 & Tachyporus chrysomelinus (L.,1758) & 2 & 0,4 & SR & ERS & Z-M & $\mathrm{R}$ \\
\hline \multicolumn{8}{|c|}{ OLISTAERINAE } \\
\hline 54 & Olisthaerus substriatus Payk.,1790 & 3 & 0,6 & SR & WRBB & $\mathrm{Z}$ & SR \\
\hline
\end{tabular}

Note: dominance groups: $D$-dominants, $S D$ - subdominants, $R$-recedents, $S R$ - sub-recedents; ecological and morphological groups according to Kashcheev: ERS - epibionts running stratobionts; ERSC - epibionts, running stratochortobionts; WDS - wells digging stratobionts; WRC - wells running coprobionts; WRBB - wells, running bark beetles; WDM - wells digging mycetobionts; WRM - wells running mycetobionts; WRS - wells running stratobionts; WRSCH - wells running stratochortobionts ; CRC - cryptobionts, running coprobionts; CDS - cryptobionts dwarfs subcortex; trophic specialization of species: $Z-$ zoophagous, $N-$ nematophagous, Z-M - zoo-mycetophagous, Z-S - zoo-saprophages, $M$ - mycetophagous; types of life strategies according to Planck: $C$ violent, $S$ - patient, $R$-explerent, $C S$-violent-patient, $C R$-violent-explerent, $S R$ - patient-explerent. 
The structure of predator beetle dominance in the analyzed biogeocenosis is represented by four classes (dominants, subdominants, recedents and subrecedents).

The highest level of numbers is characteristic of Tasgius (Rayacheila) bicharicus Mull., 1825 - this is the only dominant species in the group. The class of subdominants includes 10 species belonging to five subfamilies: Staphylininae, Oxyteliae, Oxyporinae, Steninae and Omaliinae. There are quite a number of recedents representatives of 15 species, and sub-recedents 30 species.

Representatives of eleven ecological and morphological groups were found within the beech forest ecosystem of the lower forest belt of the Gorgan massif.

According to the analysis of ecological and morphological groups, it was found that the highest level of species diversity is characteristic of the class of epibionts $-44 \%$. Within it there are representatives of only two groups: epibionts running stratobionts and epibionts running stratochortobionts.

The class of wells is $36 \%$ of the total number of species. It includes representatives of two subclasses: running wells and digging wells. There are four groups for the representatives of the first subclass: wells running coprobionts (Philonthus ventralis immundus, Philonthus longicornis, Philonthus nitidus, Philonthus decorus, Quedius (Microsaurus) xanthopus); wells running stratobionts (Siagonium quadricorne, Siagonium humerale, Abemus chloropterus, Gabrius splendidus, Othius punctultus); wells running mycetobionts: Sepedophilus testa- ceus, Sepedophilus bipustulatus; wells, bark beetlesOlistaerus substriathus.

The subclass of digging wells is characterized by the presence of 7 species, which are divided into groups: wells digging mycebionts (Oxyporus maxillosus, Oxyporus rufus ruufus); wells digging stratobionts (Tasgius (Rayacheila) morsitans compressus, Tasgius (Rayacheila) bicharicus); wells digging coprobionts (Philonthus rubripennis, Quedius (Microsaurus) paradisianus).

Cryptobionts are characterized by a fairly high number of $20 \%$. Within this class are distinguished: cryptobionts dwarf subcortex (Atrecus longiceps, Nudobius lenthus, Lordithon exoletus, L.lunulatus, L. trinitatus, L. speciosus, L.trimaculatus), and cryptobionts running stratobionts (Xantholinus linearis, Xantholinus (Purrolinus) tricolor, Hypnogyra angularis, Oxytelus sculptus).

According to the analysis of trophic specialization, zoophages are the most numerous group among Staphylinidae. These include representatives of 43 species, among which there are both specialized zoophages (Nudobius lenthus, Lodithon lunulatus) and polyphagous predators. A slightly smaller number of species feed on the type of mixotrophs, which combine the feeding characteristics of predators and saprophages and predatorsmycetophages.

Among the representatives of trophic groups found within the ecosystem of beech forests are specialized mycetophages (Micropeplus fulvipes, Oxyporus rufus rufus) and nematophages (Oxytelus sculptus, Philonthus decorus) (Fig. 1).

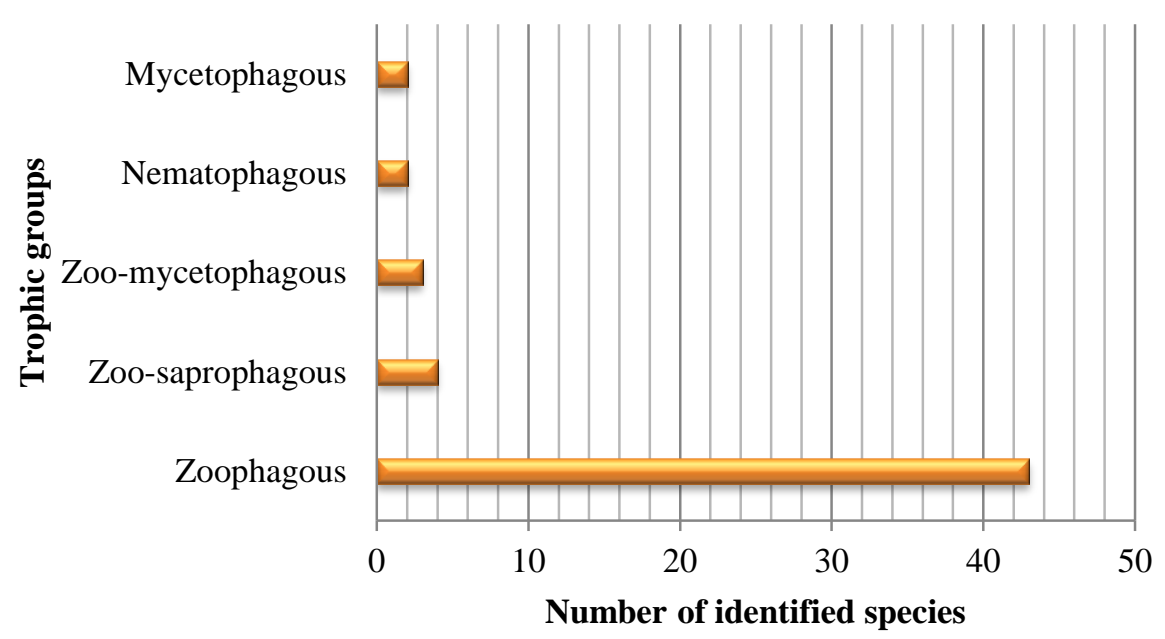

Fig. 1. Trophic structure of a group of predatory beetles in the beech forest ecosystem of the lower forest belt of the Gorgan massif

Representatives of 7 types of life strategies were found in the beeches of the lower forest belt of the Gorgany massif. Among which the highest level of species diversity is characterized by representatives of the explant type which includes representatives of the subfamilies: Piestinae (2 species), Staphylininae (11 species), Omaliinae (1 species), Oxytelinae (1 species), Scaphidinae (2 species), Steninae (1 species), Tachyporinae (5 species), Xantholininae (3 species).

A slightly lower level of species richness is characteristic of species with patient-explanatory type. These include: Oxytelinae (1 species), Staphylininae (2 spe- cies), Oxyporinae (1 species), Tachyporinae (2 species), Olistaerinae (1 species). Omalin, tachyporin and micropeplin are characterized by the patient type. Representatives of the subfamily Staphylininae (Tasgius (Rayaceila) morsitans compressus, Philonthus decorus, Quedius (Raphirus) paradisianus, Quedius (Microsaurus) xanthopus) are characterized by the presence of a violentexplanatory type of life strategies

The lowest level of species diversity is characteristic of the violent (Tasgius (Rayacheila) bicharicus, Abemus chloroptemus) and violent-patient (Lordithon lunulatus) groups. 


\section{Discussion of research results}

The results reflected in this study provide an opportunity to better understand the ecological characteristics of predatory beetles that form groups in the beeches of the lower forest belt of the Gorgan massif. In particular, the analysis of ecological and morphological groups provides a better understanding of the adaptations of Staphylinidae, in order to develop a wider range of ecological niches, and thus an understanding of the complexity of the habitat of predatory beetles.

These features of predatory beetles were studied in detail by V. A. Kashcheev, who developed a specialized system for the establishment of ecomorphs and identified morphological features for their selection [23]. Subsequently, the analysis of these features was covered in the works done by Bagach. It was he who substantiated the need to use the ecological and morphological features of predatory beetles in the analysis of the state of biogeocenoses.

It should be noted that the ecomorphological features of Stahylinidae in Ukraine have not previously been analyzed.

Study limitations. It should be noted that this study was limited exclusively to stratobiont Staphylinidae, which did not lead to a very high level of species diversity, and therefore does not allow to fully assess the variability of adaptations of the analyzed family in all groups of substrates characteristic of beeches in the Carpathian region.

Prospects for further research. Particular attention should be paid to the study of ecomorphs and life strategies of predatory beetles, as changes in the relation- ships between their groups can be used to monitor the state of the environment.

\section{Conclusions}

1. The conducted work allowed to establish that the groups of staphylinids of beech forests of the lower forest belt of the Gorgan massif are represented by individuals of 54 species belonging to 12 subfamilies. The largest share of which belongs to Staphylininae and Tachyporinae, which together make up $62.9 \%$.

2 . In the structure of dominance, the 11 most numerous species were identified, of which one dominant Tasgius (Rayacheila) bicharicus, 10 - subdominants, the other 44 species belong to the classes of recedents and sub-recedents.

3. According to the analysis of ecological and morphological classes, representatives of epibionts, wells and cryptobionts were found in the group of predatory beetles. It should be noted that a significant level of diversity of ecological niches leads to an increase in the number of cryptobiont species.

According to the analysis of life strategies of the identified species, representatives of six groups are distinguished: explanatory, patient-explanatory, patientviolent, violent, violent-patient, violent-explanatory.

By trophic specialization, the vast majority of identified species are zoophagous, but there is an increase in myxophagous, in particular predatorsmycetophagus.

\section{Conflicts of interest}

The authors declare that they have no conflicts of interest.

\section{References} 156-159.

1. Psarev, A. M. (2001). Trophic groups of scatobiont insects in Gornyi Altai. Pastures Entomological Review, 81 (1),

2. Mateleshko, O. Yu. (2008). Tverdokryli (Insecta, Coleoptera) - meshkantsi dupel derev v umovakh Ukrainskykh Karpat. Naukovyi visnyk Uzhhorodskoho universytetu. Seriia «Biolohiia», 23, 194-197.

3. Kochetova, O. S., Semenov, V. B., Zotov, V. A., Schigel, D. S. (2011). Monitoring of beetles associated with fungi using Kaila traps. Moscow University Biological Sciences Bulletin, 66 (4), 138-140. doi: http://doi.org/10.3103/s0096392511040043

4. Bogach, Ia., Sedlachek, F., Shvetsova, Z., Krivolutskii, D. A. (1988.) Zhivotnye-bioindikatory industrialnykh zagriaznenii. Zhurnal obschei biologii, 59 (5), 630-635.

5. Utrobina, N. M. (1970). Fauna i razmeschenie khischnykh zhukov (Carabidae, Staphylinidae) v Srednem Povolzhe. Materialy itog. nauchnoi konferentsii zoologov Volzhsko-Kamskogo kraia. Kazan: Izd-vo Kazanskogo Universiteta, 177-186.

6. Tikhomirova, A. L., Rybalov, L. B., Rossolimo, T. E. (1979). Fauna i ekologiia pochvennykh bespozvonochnykh (mezofauny) v sosnovykh lesakh Prioksko-Terrasnogo zapovednika. Ekosistemy iuzhnogo Podmoskovia. Moscow: Nauka, 150-180.

7. Tikhomirova, A. L. (1967). Nekotorye sravnitelnye dannye po ekologii i povedeniiu zhukov-stafilinid (Coleoptera, Staphylinidae). Zoologicheskii zhurnal, 46 (12), 1785-1798.

8. Nowicki, M. (1873). Verzeichniss galizischer Käfer. W: Beiträge zur Insektenfauna Galiziens. Krakau, 7-52.

9. Mateleshko, O. Yu. (2009). Novi ta malovidomi vydy tverdokrylykh u fauni Ukrainskykh Karpat. Visnyk zoolohii, 43 (2), 179-183.

10. Mateleshko, O. Yu. (2009). Novi znakhidky tverdokrylykh (Insecta, Coleoptera) z rehionu Ukrainskykh Karpat. Visnyk zoolohii, 45 (2), 179-183.

11. Mateleshko, O. Yu., Rizun, V. B., Chumak, V. O., Tymochko, V. B., Martynov, V. V, Petrenko, A. A. et. al. (2009). Tverdokryli (Coleoptera, Insecta) Karpatskoho natsionalnoho pryrodnoho parku. Zberezhennia ta vidtvorennia bioriznomanittia pryrodno-zapovidnykh terytorii. Sarny, 479-491. doi: http://doi.org/10.13140/RG.2.1.2950.3125

12. Mateleshko, O. Yu. (2010). Tverdokryli (Insecta, Coleoptera) - meshkantsi sirchano-zhovtoho trutovyka (Laetiporussulphureus (Bull. Ex. Fr) BondetSing) v umovakh Ukrainskykh Karpat. Naukovyi visnyk Uzhhorodskoho universytetu. Seriia «Biolohiia», 29, 177-179.

13. Fasulati, K. K. (1971). Polevoe izuchenie nazemnykh bespozvonochnykh. Moscow: Vysshaia shkola, 424.

14. Krebs, Ch. J. (1998). Ecological Methodology. Benjamin-Cummings Publishing Company, 715. 
15. Alekseev, A. V., Arnoldi, L. V., Gureva, E. L. et. al.; Bei-Bienko, G. Ia. (Ed.) (1965). Opredelitel nasekomykh evropeiskoi chasti SSSR. Vol. 2: Zhestkokrylye i veerokrylye. Moscow-Leningrad: Nauka, 668.

16. Coiffait, H. (1974). Coléoptères Staphylinidae de la région Paléartique occidentale. II. Sous famille Staphylininae, Tribus Philonthini et Staphilinini. Nouvelle Revue d'Entomologie, 593.

17. Coiffait, H. (1978). Coléoptères Staphylinidae de la région Paléartique occidentale. III. Sous famille Staphylininae, Tribu Quediini, Sous famille Paederinae, Tribu Pinophilini. Nouvelle Revue d'Entomologie, 367.

18. Lohse, G. A., Freude, H., Harde, K. (1964). Staphylinidae I (Micropeplinae bis Tachyporinae). Die Käfer Mitteleuropas. Krefeld: Goecke \& Evers, 4, 1-247.

19. Lohse, G. A., Freude, H., Harde, K. (1974). Staphylinidae II (Hypocyphtinae und Aleocharinae). Die Käfer Mitteleuropas. Krefeld: Goecke \& Evers, 5, 1-304.

20. Stocker, G., Bergmann, A. (1977). Ein Modell der Dominanz strucktur und seine Adwendung. 1. Modellbildung. Modellrealisierung. Dominanz klassen. Arch.Naturschults. U. Launds chafts forsung, 17, 1-26.

21. Kascheev, V. A. (1985). Klassifikatsiia zhiznennykh form imago stafilinid (Coleoptera, Staphylinidae). Materialy X sezda VEO, 65-67. $157-170$.

22. Kascheev, V. A. (1999). Klassifikatsiia morfologicheskikh tipov imago stafilinid. TETHYS Entomological Research, 1,

23. Vtorov, P. P., Drozdov, N. N. (2001). Biogeografiia. Moscow: Visshaia shkola, 301.

Received date 12.05.2020

Accepted date 15.06.2020

Published date 30.06.2020

Lutska Mariana, Postgraduate Student, Department of Biology and Ecology, State Higher Educational Institution "Vasyl Stefanyk Precarpathian National University", Shevchenka str., 57, Ivano-Frankivsk, Ukraine, 76018

E-mail: mariana.93.if@ukr.net

Artur Sirenko, PhD, Associate Professor, Department of Biology and Ecology, State Higher Educational Institution "Vasyl Stefanyk Precarpathian National University", Shevchenka str., 57, Ivano-Frankivsk, Ukraine, 76018

E-mail: bratlibo@yahoo.co.uk 